\title{
Biometry, Emergence and Initial Growth of Accessions and Mangaba Progenies
}

\author{
Adrielle Naiana Ribeiro Soares ${ }^{1}$, Ana Veruska Cruz da Silva ${ }^{2}$, Evandro Neves Muniz $^{2}$, \\ Marília Freitas de Vasconcelos Melo ${ }^{3}$, Priscilla Santana Santos ${ }^{4} \&$ Ana da Silva Ledo ${ }^{2}$ \\ ${ }^{1}$ Federal University of Sergipe, São Cristovão, SE, Brazil \\ ${ }^{2}$ Embrapa Tabuleiros Costeiros, Aracaju, SE, Brazil \\ ${ }^{3}$ Federal University of Alagoas, Maceió, AL, Brazil \\ ${ }^{4}$ Faculdade do Nordeste da Bahia, Coronel João Sá, BA, Brazil \\ Correspondence: Adrielle Naiana Ribeiro Soares, Federal University of Sergipe, São Cristovão, Sergipe, Brazil. \\ E-mail: adrielle.naiana@hotmail.com
}

Received: September 11, 2018

Accepted: January 19, 2019

Online Published: March 15, 2019

doi:10.5539/jas.v11n4p436

URL: https://doi.org/10.5539/jas.v11n4p436

\begin{abstract}
Mangaba (Hancornia speciosa Gomes) is a native fruit of great economic, cultural, and environmental importance in its areas of occurrence. Due to extractive activities and real estate pressure, the number of natural populations has considerably decreased. The propagation of the species is still one of the primary obstacles for orchard implantations, thus, studies that provide a better understanding of the dynamics of the species' growth should be developed. This work aimed to evaluate the biometry, emergence, and initial growth of mangaba progenies (Hancornia speciosa Gomes), using the plant material from the Active Germplasm Bank of Embrapa Coastal Tablelands, located in Itaporanga d'Ajuda, SE, Brazil. Treatments consisted of progenies from 17 accessions. The experiment was carried out in a completely randomized design with four replications of 25 seeds. Number of seeds per fruit, as well as fruit and seed weight $(\mathrm{g})$, length $(\mathrm{mm})$, width $(\mathrm{mm})$, and thickness (mm) were evaluated. For emergence and initial growth, the following variables were analyzed: percentage of emergence (PE\%), emergence speed index (ESI\%), survival rate (SR\%), height $(\mathrm{H})$, stem diameter (SD), and the number of leaves (NL). Biometric analyses of fruits and seeds revealed significant phenotypic variability among mangaba accessions. Progenies of the accessions LGP1, LGP3, LGP4, PTP4, TCP2, TCP6, ABP1, ABP2, ABP4 and BIP4 showed better results for all emergence and initial growth variables. The progenies of accessions TCP1, BIP4, CAP5 and PRP5 expressed lower emergence and survival percentages, and low vigor.
\end{abstract}

Keywords: ex situ conservation, fruits, genetic variability, Hancornia speciosa Gomes, native, seeds

\section{Introduction}

Hancornia speciosa Gomes (family Apocynaceae) is a tree fruit native to Brazil, found in the coastal tablelands, coastal lowlands, and in the Cerrado Biome. Its fruit is used as raw material for the manufacture of several by-products, such as jelly, ice cream, juice, jam, sauce, wine, and vinegar (Costa, Silva, Ledo, Santos, \& Silva Júnior, 2011). For this reason, this specie has aroused the interest of the food industry sector.

Despite its agroindustrial potential, this specie is mostly exploited by an extractive way. The areas of natural occurrence have undergone accelerated genetic erosion due to great real estate pressure, mainly in the coastal lowland of the Brazilian northeast.

Mangaba is usually sexually propagated. However, the species presents recalcitrant seeds, and its pulp contains inhibitory substances, which may prevent or hinder germination (Vieira Neto, Silva Junior, \& Ledo, 2009). These facts contribute to the low germination rate and slow and uneven seedling growth. Therefore, propagation is one of the major bottlenecks for the species production.

Aiming at the conservation and future improvement of this plant, the Mangaba Active Germplasm Bank (AGB) of Embrapa Coastal Tablelands was implemented in 2009 at the Experimental Field of Itaporanga d'Ajuda-SE, in a Restinga area, in Brazil. The AGB currently contains 271 accessions, propagated by open-pollinated seeds from the States of Bahia, Paraíba, Sergipe, Pernambuco, Alagoas, Ceará, Pará and Minas Gerais. The 
characterization of accessions is fundamental to the knowledge of their potential and the identification of the variability among them (Lima et al., 2012). Moreover, information on the propagation is essential and must precede orchards implantation.

The physiological quality of seeds is influenced by the genotype, and the maximum seed quality potential, such as germination and vigor, is genetically controlled (Prete \& Guerra, 1999). Therefore, research involving the divergence and genetic relationships for traits related to physiological quality assist in creating selection strategies for the improvement of seed physiological quality (Cardoso, Silva, Pereira, Viana, \& Araújo, 2009). In selection programs, diversity can be early verified by the seed quality, using germination and vigor tests (Dias \& Marcos Filho, 1995).

Plant breeding programs usually aim at high-quality cultivars. Studies on seeds, using physiological tests, may contribute to developing methods for the selection of high-quality-seeds genotypes (Moura, Chaves, Naves, Aguiar, \& Sobierajski, 2013). Growth analyses can also be used to describe plant morphophysiological conditions, phenotypic differences, and effects of ecological phenomena on the growth and adaptability of species to different ecosystems (Magalhães, 1986).

Fruit and seed biometry is another relevant tool to detect genetic variability in populations of the same species and the relationships with environmental factors (Gonçalves et al., 2013). Tropical tree species have a great variety of traits, such as fruit size, number of seeds per fruit, seeds size, and seeds dimension. Thus, the biometric characterization can be a relevant subsidy for species differentiation (Cruz, Carvalho, \& Leão, 2001). Despite the economic, social, and environmental importance of mangaba, research involving fruits and seeds biometry is still incipient, requiring further studies.

Understanding the development is crucial to creating management strategies for mangaba in its region of origin. Furthermore, some genetic resources with potential traits can be incorporated into the productive process (Vieira, Souza, Belo, \& Camilo, 2013). However, there is a lack of studies on the several aspects involved in mangaba propagation. Works addressing this topic are paramount for future breeding programs that aim at better conservation and utilization of this fruit.

This work aimed to evaluate the biometry, and emergence and initial growth of accessions and progenies from the Mangaba Active Germplasm Bank of Embrapa Coastal Tablelands.

\section{Method}

This study used the plant material from the Active Germplasm Bank of Embrapa Coastal Tablelands, located at

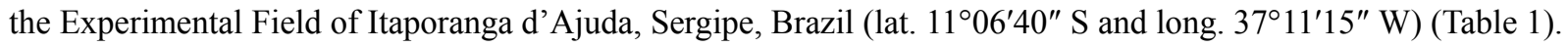
Twenty-five fruits per accession were collected in June 2015. Afterward, fruits were taken to the Seed Analysis Laboratory of Embrapa Coastal Tablelands, where the biometric analyses and seed processing were carried out.

Table 1. Origin, matrix (mother plant that originated the progeny), and accession code of the Active Germplasm Bank of Embrapa Coastal Tablelands, Itaporanga d'Ajuda, SE, Brazil

\begin{tabular}{lll}
\hline Origin & Matrix & Accession/Code \\
\hline Mata de São João, BA & P1 & Lagoa Grande-LGP1 \\
Mata de São João, BA & P3 & Lagoa Grande-LGP3 \\
Mata de São João, BA & P4 & Lagoa Grande-LGP4 \\
Indiaroba, SE & P1 & Pontal-PTP1 \\
Indiaroba, SE & P2 & Pontal-PTP2 \\
Indiaroba, SE & P4 & Pontal-PTP4 \\
Indiaroba, SE & P5 & Pontal-PTP5 \\
Indiaroba, SE & P1 & Terra Caída-TCP1 \\
Indiaroba, SE & P2 & Terra Caída-TCP2 \\
Indiaroba, SE & P6 & Terra Caída-TCP6 \\
Salvaterra, PA & P1 & Água Boa-ABP1 \\
Salvaterra, PA & P2 & Água Boa-ABP2 \\
Salvaterra, PA & P4 & Água Boa-ABP4 \\
Conde, BA & P2 & Barra de Itariri-BIP2 \\
Conde, BA & P4 & Barra de Itariri-BIP4 \\
Jandaíra, BA & P5 & Costa Azul-CAP5 \\
Indiaroba, SE & P5 & Preguiça-PRP5 \\
\hline
\end{tabular}




\subsection{Fruit and Seed Biometry}

Twenty-five fruits per accession (Figures 1A and 1B), selected by visual and phytopathological integrity. The following parameters were evaluated:

Fruit weight: by using an analytical scale, expressed in g;

Fruit diameter, width, and thickness: by using a digital caliper, expressed in $\mathrm{mm}$;

Number of seeds per fruit: by counting;

Seed weight: by using an analytical scale, measuring the fresh weight of seeds, expressed in g;

Seed diameter, width, and thickness: by using a digital caliper, expressed in $\mathrm{mm}$.

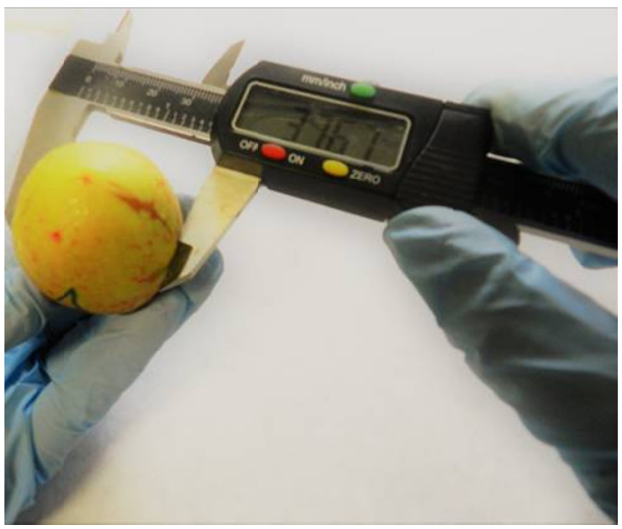

A

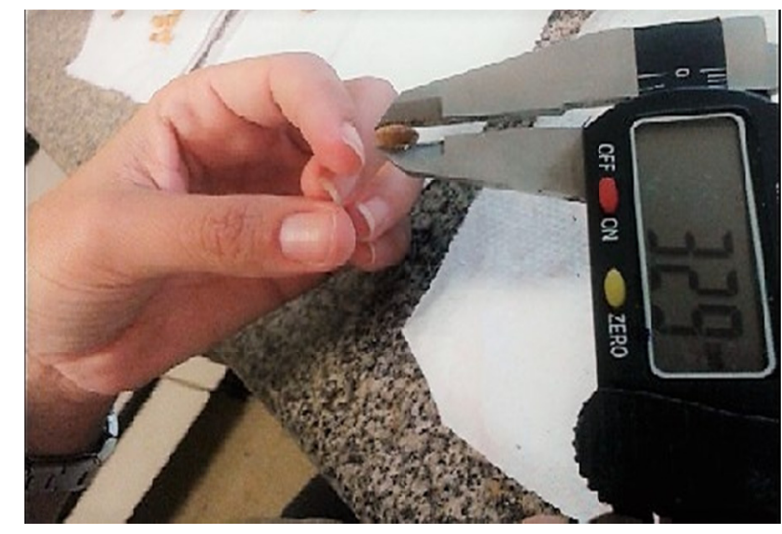

B

Figura 1. Examples of biometric evaluation of fruits (A) and seeds (B) of accesses of the Embrapa Germplasm Active Bank of Tabuleiros Costeiros, Itaporanga d'Ajuda, SE, Brazil

A descriptive analysis of the results was performed. The groups were represented by the Principal Component Analysis (PCA) of the FactoMineR package (Husson, Josse, \& Lê, 2008). The correlation matrix was calculated using the Pearson's correlation, with significance level $(\mathrm{p}<0.05)$. All analyses were performed in the R software, version 3.3.3 (R Core Team, 2017).

\subsection{Emergence and Initial Growth}

After the beneficiation of the seeds, they were sown in polyethylene bags $(16 \times 24 \mathrm{~cm})$ containing washed sand as substrate. Treatments consisted of the different accessions (Table 1). Seedlings remained in the greenhouse throughout the evaluation period (Figures $2 \mathrm{~A}-2 \mathrm{C}$ ), and the following tests and determinations were performed:

Emergence test: performed based on the recommendations of the Rules for Seed Analysis (RAS) (MAPA, 2009). Counts started at 15 days after sowing. Percentage of emergence was determined at 55 days after sowing, considering as normal the seedlings that presented well-developed essential structures;

Emergence speed index: carried out simultaneously with the emergence test, with daily counts, from 15 days after sowing until the end of the test. The index was calculated according to the formula:

$$
\mathrm{ESI}=\mathrm{E} 1 / \mathrm{N} 1+\mathrm{E} 2 / \mathrm{N} 2+\ldots \mathrm{En} / \mathrm{Nn}
$$

where, ESI = emergence speed index; E1, E2 and En = number of normal seedlings, computed in the first, second ... and last count, respectively; N1, N2, Nn = number of sowing days to the first, second ... and last count, respectively (Maguire, 1962);

Seedling height: evaluated throughout the period in the greenhouse, measured with a ruler graduated in centimeter, from the base to the apex of the stem;

Stem diameter: determined monthly, using a digital caliper;

Number of leaves: evaluated monthly, by counting the number of leaves per plant;

Survival rate: calculated at the end of the experiment, expressed as a percentage. 

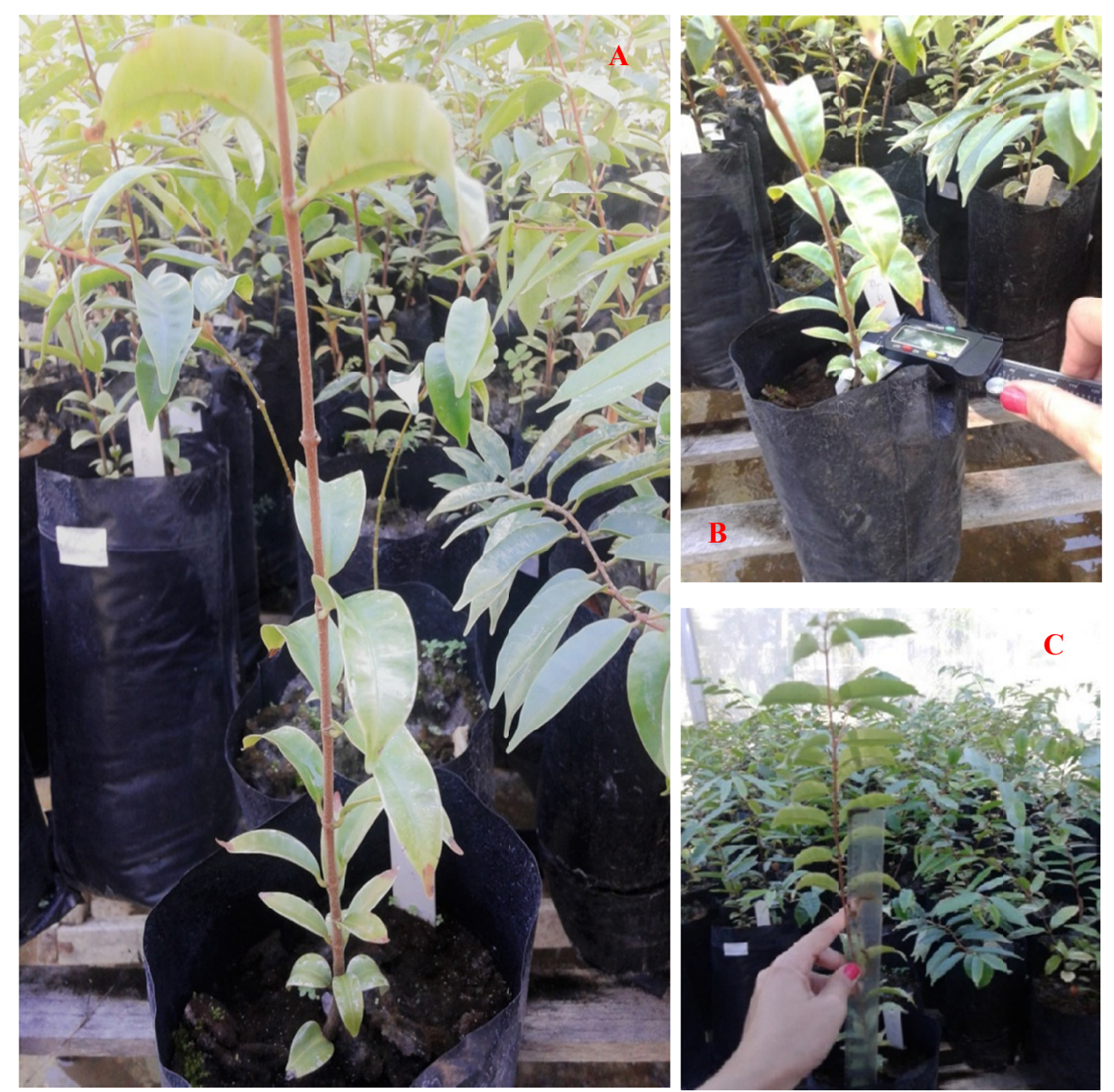

Figure 2. Progeny of mangaba at six months after sowing (A); evaluation of stem diameter (B) and height (C). Itaporanga d'Ajuda, SE, Brazil

The experiment consisted of a completely randomized design, with four replications of 25 seeds, totaling 100 seeds per treatment. Data obtained from the variables measured for emergence and initial growth experiments were subject to analysis of variance and the Duncan's mean test at the $5 \%$ probability level, using the Statistical Analysis System (SAS) software, version 9.1 (SAS Institute, 2011).

\section{Results and Discussion}

\subsection{Fruit and Seed Biometry}

A considerable asymmetry was observed between the accessions' matrices (Figure 3). Fruit weight (Figure 3A) ranged from 11 to $38 \mathrm{~g}$. Fruit length, width, and thickness (Figures 3B-3D) varied between 22 and $43 \mathrm{~mm} ; 21$ and $41 \mathrm{~mm}$; and 12 and $38 \mathrm{~mm}$, respectively. Number of seeds per fruit ranged from 3 to 32 (Figure 3E). The accessions ABP4 and TCP6 stood out for these traits, except for length. The accession CAP5 presented the lowest values for all the evaluated traits. 

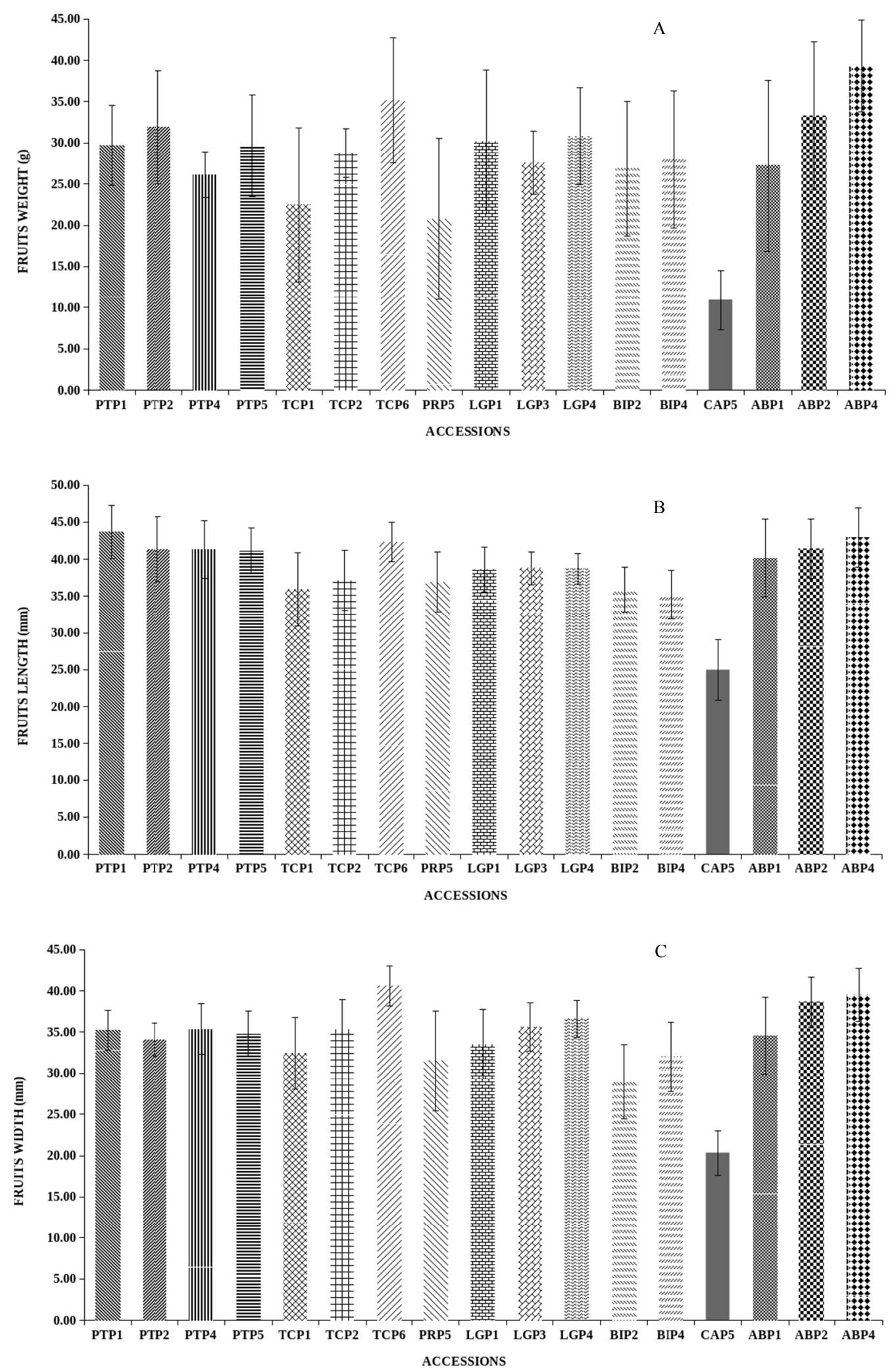

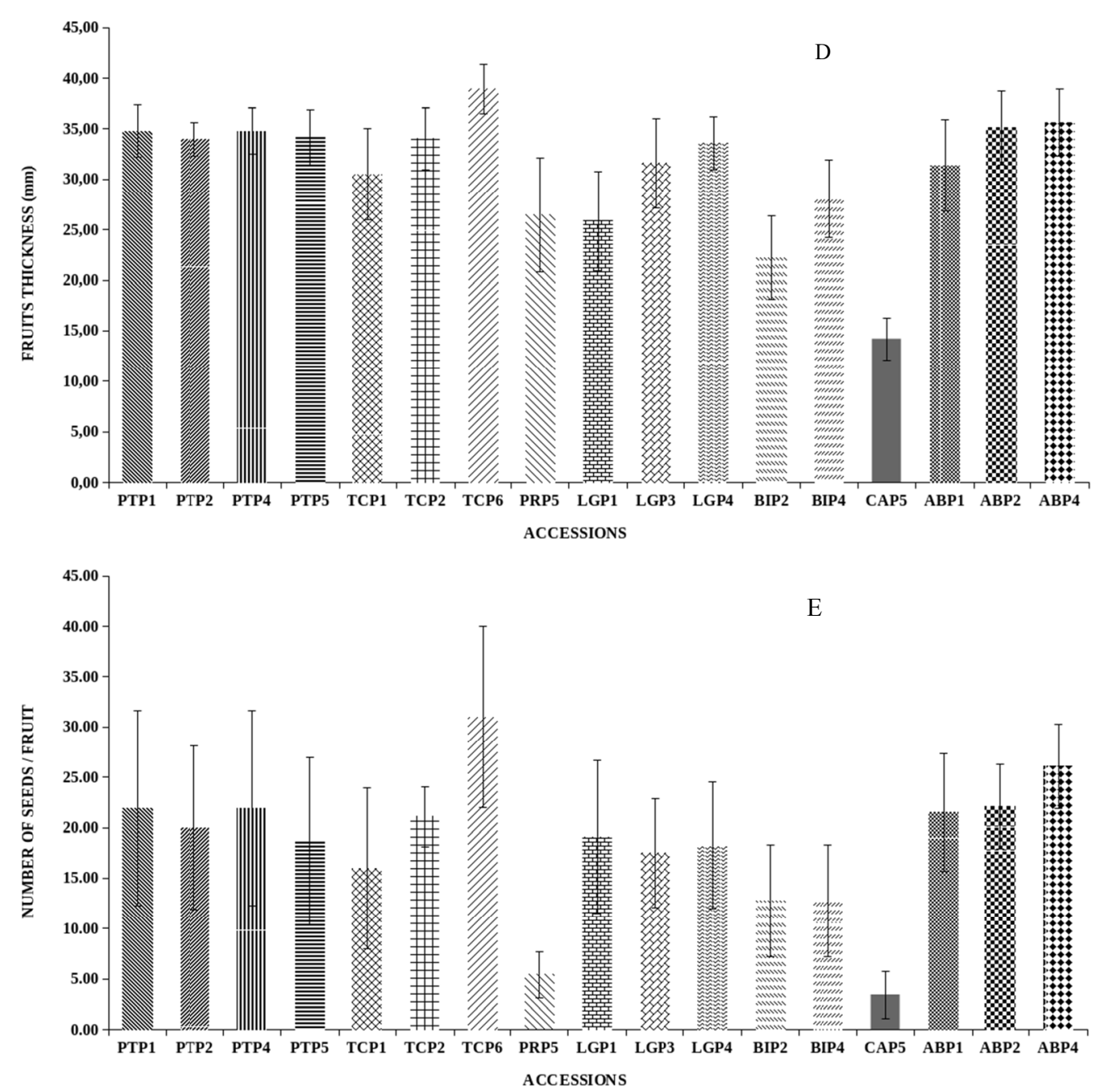

Figure 3. Fruits weight (A), length (B), width (C), thickness (D), and number of seeds per fruit (E) of mangaba accessions of the Active Germplasm Bank of Embrapa Coastal Tablelands, Itaporanga d'Ajuda, SE, Brazil

The results verified for the biometry of the fruits may be related to the non-domestication of the mangabeira, which implies that the traits considered in the breeding have not yet been elucidated (Ganga, Ferreira, Chaves, Naves, \& Nascimento, 2010). However, larger and heavier fruits are usually more appreciated by the in natura market.

The asymmetry may be indicative of high genetic variability between plants. However, biometric traits are quite variable in function of environmental conditions; genotype/environment interaction may be responsible for the phenotypic variation (Barros \& Souza Júnior, 2009). The wide variation in phenotypic traits, together with genetic variability, is typical in allogamous plants, mainly in non-domesticated species. This fact can favor the selection of traits in breeding programs (Farias Neto, Carvalho, \& Muller, 2004).

Studies on biometric traits of mangaba showed a range from 7.6 to $126 \mathrm{~g}$ for fruit weight (Vieira et al., 2017). Zuffo, Andrade, and Zuffo Júnior (2014) evaluated the biometric traits of baru (Dipteryx alata Vog.) and reported variations in fruit length $(57.78-62.16 \mathrm{~mm})$, width $(41.10-43.08 \mathrm{~mm})$, and thickness $(29.95-33.55 \mathrm{~mm})$. Similar results were observed by Gonçalves et al. (2013) in a study on the biometry of mangaba fruits and seeds, in which $33 \%$ of the fruits analyzed had more than 25 seeds per fruit. This trait is important for the species propagation, considering the recalcitrant seeds (Vieira Neto, 2002). The results for seed weight obtained in this work were inferior to those reported by Vieira et al. (2017), who verified a mean seed weight per fruit of $3.7 \mathrm{~g}$, and to those presented by Nascimento, Cardoso, \&and Cocozza (2014), who obtained mean seeds weight per fruit of $2.40 \mathrm{~g}$. 
Seeds biometric characteristics demonstrated significant variation. The accession LGP1 presented the highest value for seed weight $(2.3 \mathrm{~g})$, followed by BIP2 $(2.2 \mathrm{~g})$ (Figure 4A). The accessions BIP2 and CAP5 had the highest values for seed length, width, and thickness, ranging from 6 to $9 \mathrm{~mm}, 6$ to $7 \mathrm{~mm}$, and 3.3 and $3.1 \mathrm{~mm}$, respectively (Figures 4B-D). For the number of seeds per fruit, these same accessions obtained smaller values when compared with those with better results. However, the seeds of the accessions BIP2 and CAP5 had higher dimension values than those from fruits with a greater number of seeds.
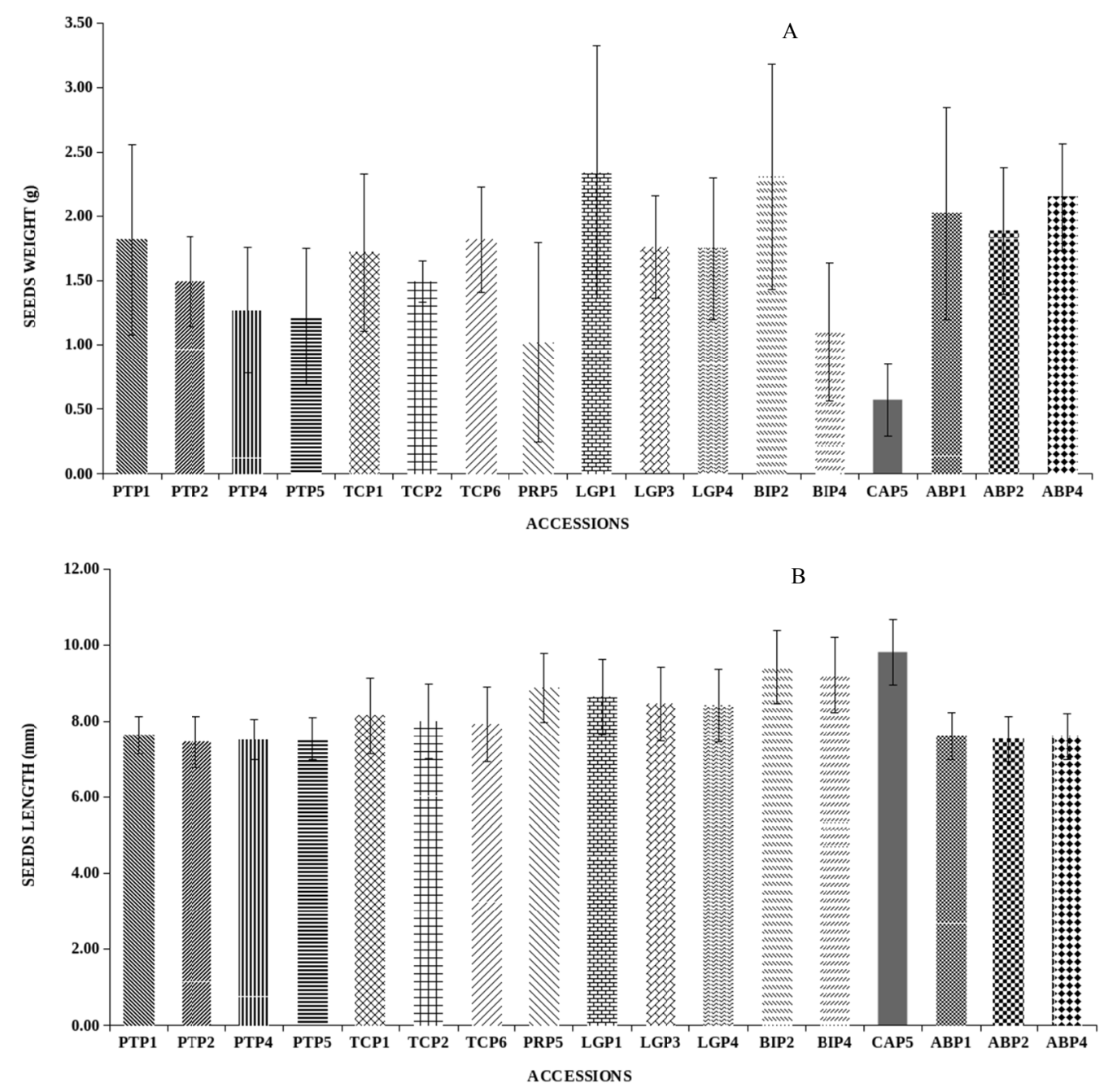

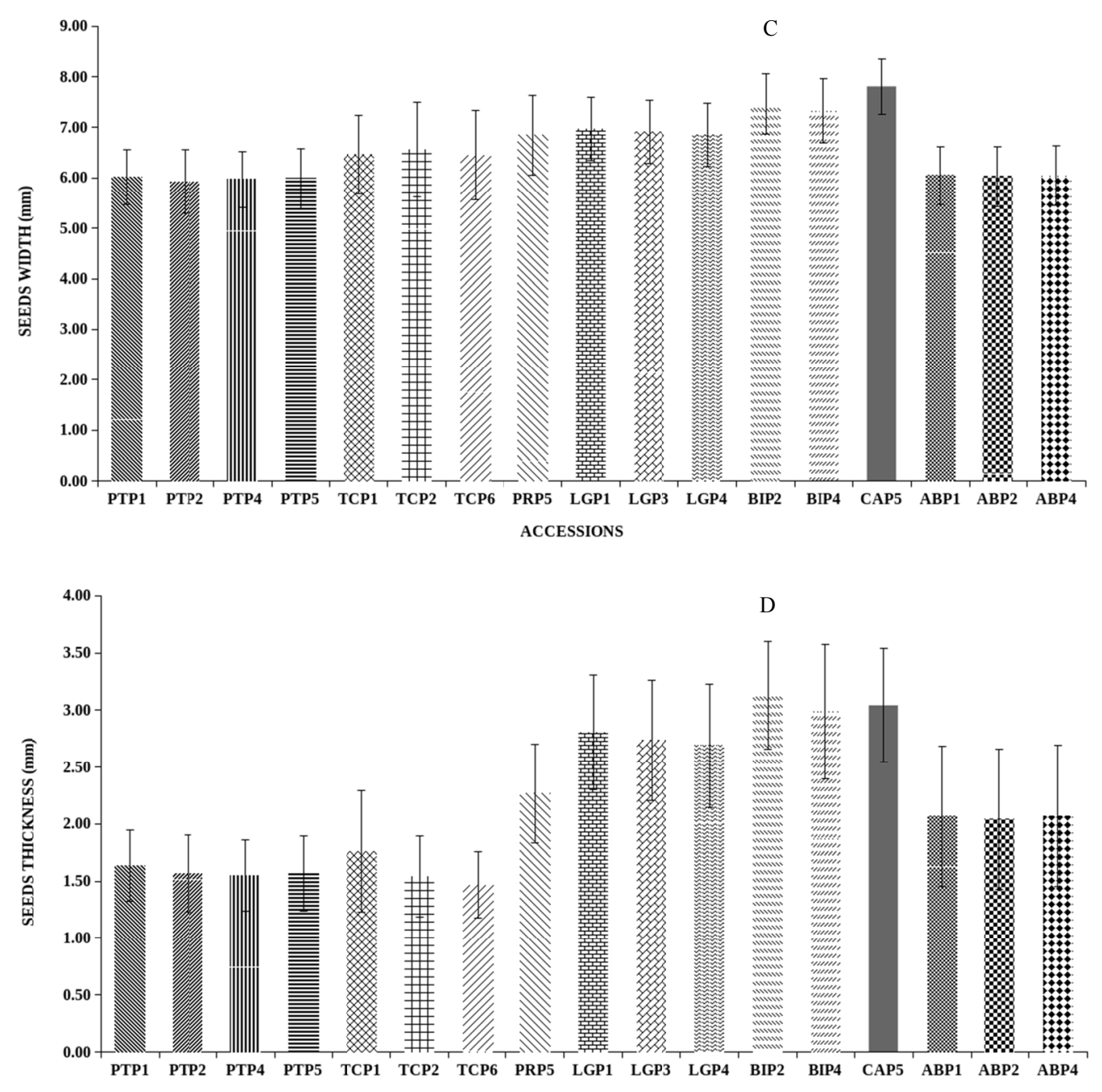

ACCESSIONS

Figure 4. Seeds weight (A), length (B), width (C), and thickness (D) of seeds of mangaba accessions of the Active Germplasm Bank of Embrapa Coastal Tablelands, Itaporanga d'Ajuda, SE, Brazil

In some species, a single tree may present fruits with different seed size. Conversely, other species have seeds with similar sizes, changing only the number of seeds instead of the weight (Vaughton \& Ramsey, 1998). Seeds did not follow an emergence pattern, based on the seed size, since the accessions that showed higher percentages of emergence had smaller seeds. Although larger seeds are related to the high percentage of emergence, it can be stated that CAP5 is not a promising accession for the establishment of seedlings in the environment due to the lower results regarding emergence and vigor.

In this case, the genetic information of each accession was the fact that mostly influenced since seedlings were cultivated under the same environmental conditions. This result reinforces the hypothesis that the matrices have genetic variability and confirms that different changes can occur within each individual, and thus, phenotypic variations of fruits and seeds may happen because they come from different matrices or mother plant (Villachica, 1996).

Studies on the biometry of fruits and seeds are important for the formation of germplasm collections, as well as for the improvement of the desirable traits, either for the increase or the uniformity. These works assist breeding programs in developing cultivars with fruits that meet the market's requirements (Gonçalves et al., 2013).

The Principal Component Analysis (PCA) (Figure 5) revealed two distinct groups. The accessions CAP5 and PRP5 were the most isolated, and the first two principal components accounted for a variation of $70.21 \%$. This type of analysis is relevant for germplasm characterization for providing the clustering of a set of accessions, based on several existing traits (Rojas et al., 2003). 


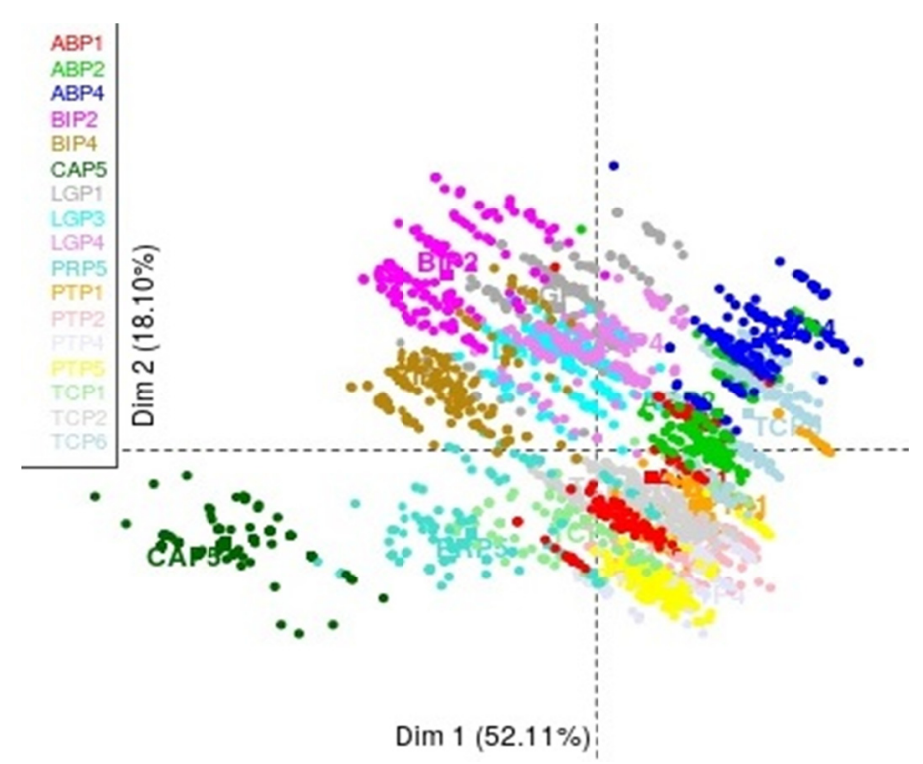

Figura 5. Principal Component Analysis (PCA) for the biometry of fruits and seeds of mangaba accessions of the Active Germplasm Bank of Embrapa Coastal Tablelands, Itaporanga d'Ajuda, SE, Brazil

The Pearson's correlation (Table 2) revealed a positive and high correlation between fruit width and thickness. Fruit size (length, width, thickness) and fruit weight also correlated positively. Fruit weight positively correlated to seed weight per fruit and number of seeds per fruit. These results indicate that heavier fruits are dependent on a greater number of seeds, which is directly related to efficient pollination (Ganga et al., 2010). This information is in agreement with that reported by Gonçalves et al. (2013) and Nascimento et al. (2014) regarding biometric variables of mangaba fruits and seeds.

Table 2. Pearson's correlation for fruit length, fruit width, fruit thickness, fruit weight, number of seeds per fruit, seed length, seed thickness, seed width, and seed weight of mangaba accessions of the Active Germplasm Bank of Embrapa Coastal Tablelands, Itaporanga d'Ajuda, SE, Brazil

\begin{tabular}{|c|c|c|c|c|c|c|c|c|c|}
\hline & FL & FWi & FT & FEw & NSF & SL & ST & SWi & SWe \\
\hline $\mathrm{FL}$ & 1.00 & & & & & & & & \\
\hline FWi & $0.70^{* *}$ & 1.00 & & & & & & & \\
\hline FT & $0.68^{* *}$ & $0.89 * *$ & 1.00 & & & & & & \\
\hline FEw & $0.61^{* *}$ & $0.71^{* *}$ & $0.587^{* *}$ & 1.00 & & & & & \\
\hline NSF & $0.40^{* *}$ & $0.55^{* *}$ & $0.56^{* *}$ & $0.58^{* *}$ & 1.00 & & & & \\
\hline SL & $-0.29 * *$ & $-0.25^{* *}$ & $-0.40 * *$ & $-0.08^{*}$ & $-0.31^{* *}$ & 1.00 & & & \\
\hline ST & $-0.25^{* *}$ & $-0.21 * *$ & $-0.44 * *$ & $-0.01^{\mathrm{ns}}$ & $-0.25^{* *}$ & $0.50 * *$ & 1.00 & & \\
\hline SWi & $-0.26^{* *}$ & $-0.23^{* *}$ & $-0.36^{* *}$ & $-0.06^{\mathrm{ns}}$ & $-0.29 * *$ & $0.71 * *$ & $0.49 * *$ & 1.00 & \\
\hline SWe & $0.29 * *$ & $0.39 * *$ & $0.20^{* *}$ & $0.57 * *$ & $0.51^{* *}$ & $-0.02^{\mathrm{ns}}$ & $0.18^{* *}$ & $0.0145^{\mathrm{ns}}$ & 1.00 \\
\hline
\end{tabular}

Note. $\mathrm{FL}=$ fruit length; $\mathrm{FWi}=$ fruit width; $\mathrm{FT}=$ fruit thickness; Few $=$ fruit weight; $\mathrm{NSF}=$ number of seeds per fruit; $\mathrm{SL}=$ seed length; $\mathrm{ST}=$ seed thickness; $\mathrm{SWi}=$ seed width; $\mathrm{SWe}=$ seed weight.

**: significant at $1 \%$ probability; *: significant at a $5 \%$ at probability; ${ }^{\text {ns }}$ : no significant.

The association between traits is important since it allows analyzing the degree of influence of one trait on another, as well as performing direct selection (Zuffo et al., 2016). Studies involving multivariate analysis enable the estimation of the diversity between accessions, as well as the knowledge of the available germplasm. Moreover, they contribute to a better selection of accessions by eliminating the ones that are closer and allowing the selection of desirable attributes to be used in the characterization (Mariot \& Barbieri, 2010). 
The present results demonstrated high levels of phenotypic variability for fruits and seeds of mangaba accessions, requiring an in-depth study to identify important traits for the production of fruits and genotypes of commercial interest.

\subsection{Emergence and Initial Growth}

The studied accessions showed differences for percentage of emergence, emergence speed index, and survival rate (Table 3). The progenies of the accessions from the states of Bahia (LGP1, LGP3, and LGP4), Sergipe (PTP4, PTP5, TCP2, and TCP6), and Pará (ABP1 and ABP2) obtained higher percentages of emergence.

Table 3. Percentage of emergence, emergence speed index and survival rate of progenies of mangaba accessions of the Active Germplasm Bank of Embrapa Coastal Tablelands, Itaporanga d'Ajuda, SE, Brazil

\begin{tabular}{llll}
\hline ACESSIONS & PE $(\%)$ & ESI & SR (\%) \\
\hline LGP1 & $100 \mathrm{a}$ & $1.34 \mathrm{a}$ & $100 \mathrm{a}$ \\
LGP3 & $100 \mathrm{a}$ & $1.29 \mathrm{ab}$ & $100 \mathrm{a}$ \\
LGP4 & $100 \mathrm{a}$ & $1.17 \mathrm{abcd}$ & $100 \mathrm{a}$ \\
PTP1 & $95 \mathrm{ab}$ & $1.04 \mathrm{~cd}$ & $100 \mathrm{a}$ \\
PTP2 & $95 \mathrm{ab}$ & $1.15 \mathrm{abcd}$ & $75 \mathrm{c}$ \\
PTP4 & $100 \mathrm{a}$ & $1.07 \mathrm{bcd}$ & $100 \mathrm{a}$ \\
PTP5 & $100 \mathrm{a}$ & $1.02 \mathrm{~cd}$ & $100 \mathrm{a}$ \\
TCP1 & $47 \mathrm{~d}$ & $0.64 \mathrm{e}$ & $61 \mathrm{~d}$ \\
TCP2 & $100 \mathrm{a}$ & $1.24 \mathrm{abc}$ & $100 \mathrm{a}$ \\
TCP6 & $100 \mathrm{a}$ & $0.98 \mathrm{~d}$ & $100 \mathrm{a}$ \\
ABP1 & $100 \mathrm{a}$ & $1.20 \mathrm{abcd}$ & $88 \mathrm{~b}$ \\
ABP2 & $100 \mathrm{a}$ & $1.14 \mathrm{abcd}$ & $100 \mathrm{a}$ \\
ABP4 & $90 \mathrm{abc}$ & $1.04 \mathrm{~cd}$ & $100 \mathrm{a}$ \\
BIP2 & $85 \mathrm{bc}$ & $1.04 \mathrm{~cd}$ & $100 \mathrm{a}$ \\
BIP4 & $45 \mathrm{~d}$ & $0.59 \mathrm{e}$ & $54 \mathrm{e}$ \\
CAP5 & $55 \mathrm{~d}$ & $0.58 \mathrm{e}$ & $54 \mathrm{e}$ \\
PRP5 & $45 \mathrm{~d}$ & $0.61 \mathrm{e}$ & $51 \mathrm{e}$ \\
CV \% & 11.8 & 13.9 & 1.7 \\
\hline
\end{tabular}

Note. $\mathrm{PE} \%=$ Percentage of Emergence; ESI = Emergence Speed Index; SR\% = Survival Rate.

The vigor of the plants verified by the percentage of emergence was better expressed in plants from the accessions LGP1, LGP3, LGP4, PTP2, PTP4, TCP2, ABP1, and ABP2. The progenies of the accessions PTP2, TCP1, BIP4, CAP5, and PRP5 had the lowest survival rates. Most of the accessions that obtained better results for percentage of emergence were also more vigorous. Thus, it is inferred that percentage of emergence correlates to ESI and that it is possible to select progenies that express faster establishment.

Emergence and plant vigor are target traits in breeding programs (Oliveira, Lopes, Chaves, Martins, \& Alves, 2013). Thus, seeds genetic attributes have considerable importance since the seedlings originated from them will certainly reflect their capacity to form superior individuals (Vechiato \& Parisi, 2013). The relative contribution of each trait to genetic variability is essential for the selection of traits of greater interest, as well as for the discard of those that little contribute to genotypes differentiation (Correa \& Gonçalves, 2012).

The determination of adequate propagation procedures can be a primordial factor for the domestication and commercial cultivation of a species, aiming to obtain high-quality seedlings that comply with the commercial standard (A. V. Pereira, E. B. C. Pereira, Junqueira, \& Fialho, 2002). In mangaba, the study of genotypes to obtain propagation material is crucial for the future introduction of this species to commercial fields.

Variations in the percentage of emergence, ESI, and survival rate were detected in other studies, such as that of Silva, Mota, and Farias Neto (2009), who reported percentage of emergence ranging from $27.9 \%$ to $98.9 \%$ among progenies of bacabi (Oenocarpus mapora Karsten) and bacaba (Oenocarpus distichus Mart.). Freitas and Costa (2015) verified differences in the emergence speed index in progenies of Eugenia calycina, ranging from 0.160 and 0.289. Studies with pequi seeds (Caryocar brasiliense Camb) revealed a variation in survival rate between progenies, ranging from 50 to $100 \%$, with a mean of $93.4 \%$ (Moura et al., 2013). 
A continuous growth was observed throughout the evaluations, and significant variations were detected among the progenies for the analyzed traits (Table 4). The progenies of the ABP4 access obtained higher height (45.10 $\mathrm{cm}) ;(4.43 \mathrm{~mm})$ and the TCP6 and BIP4 accessions, with the highest number of leaves. For all initial growth variables the progenies of the CAP5 accessions reached lower values, being lower than the others.

The study on plant growth is fundamental to increase the field of knowledge regarding genotypes behavior. The morphological parameters are widely used to determine seedlings quality standard. Thus, the knowledge of morphological variability allows selecting materials with better possibilities of domestication. Understanding the plant development is essential for the management of mangaba due to materials that have potential traits to be introduced to the production chain (Vieria et al., 2013) in mangaba seedlings.

The variation in the germinative behavior of progenies may be associated with the genetic information of each accession since they have different origins. This fact reinforces the hypothesis that plants originating from geographically distinct regions may present high variability. Thus, the knowledge about this genetic material is fundamental to the selection of the best parents in order to obtain genotypes with superior traits.

\section{References}

Barros, S. C. L., \& Souza Júnior, C. L. (2009). Interação de genótipos com ambientes no melhoramento de plantas. Seminários em genética e melhoramento de plantas departamento de genética (p. 105). Piracicaba, Brasil.

Cardoso, D. L., Silva, R. F., Pereira, M. G., Viana, A. P., \& Araújo, E. F. (2009). Genetic diversity and genetic parameters related to physiological seed quality in papaya germplasm. Revista Ceres, 56, 572-579.

Correa, A. M., \& Gonçalves, M. C. (2012). Genetic divergence in common bean genotypes grown in the State of Mato Grosso do Sul. Revista Ceres, 59, 206-212. https://doi.org/10.1590/S0034-737X2012000200009

Costa, T. S., Silva, A. V. C., Ledo, A. S., Santos, A. R. F., \& Silva Júnior, J. F. (2011). Genetic diversity of accessions of the mangaba germplasm bank in Sergipe, Brazil. Pesquisa Agropecuária Brasileira, 46, 499-508. https://doi.org/10.1590/S0100-204X2011000500007

Cruz, E. D., Carvalho, J. E. U., \& Leão, N. V. M. (2001). Methods for Overcoming Dormancy and Fruit and Seed Biometry in Parkia nitida Miquel. (Leguminosae-Mimosoideae). Acta Amazônica, 31, 167-177. https://doi.org/10.1590/1809-43922001312177

Dias, D. C. F. S., \& Marcos Filho, J. (1995). Testes de vigor baseados na permeabilidade das membranas celulares: I. Condutividade elétrica. Informativo Abrates, 5, 26-33.

Farias Neto, J. T., Carvalho, J. U., \& Muller, C. H. (2004). Estimates correlation and repeatability for characters of the bacurizeiro fruit. Ciência e Agrotecnologia, 28, 300-305. https://doi.org/10.1590/S1413-70542004 000200008

Freitas, M. B. F., \& Costa, R. R. G. F. (2015). Estimates of genetic variance components in and between progeny of red-pitanga. Global Science Technology, 8, 78-86. https://doi.org/10.14688/1984-3801/gst.v8n3p78-86

Ganga, R. M. D., Ferreira, G. A., Chaves, L. J., Naves, R. V., \& Nascimento, J. L. (2010). Caracterização de Frutos e Árvores de Populações Naturais de Hancornia speciosa Gomes do Cerrado. Revista Brasileira de Fruticultura, 32, 111-113. https://doi.org/10.1590/S0100-29452010005000019

Gonçalves, L. G. V., Andrade, F. R., Marimon Junior, B. H., Schossler, T. R., Lenza, E., \& Marimon, B. S. (2013). Biometry of fruits and seeds mangaba (Hancornia speciosa Gomes) in natural vegetation in the eastern region of Mato Grosso, Brazil. Revista de Ciências Agrárias, 36, 31-40.

Husson, F., Josse, J., \& Lê, S. (2008). FactoMineR: An R package for multivariate analysis. Journal of Statistical Software, 25, 1-18. https://10.18637/jss.v025.i01

Lima, M. S., Carneiro, J. E. S., Carneiro, P. C. S., Pereira, C. S., Vieira, R. F., \& Cecon, P. R. (2012). Genetic divergence among cowpea UFC germplasm bank accessions. Crop Breeding and Applied Biotechnology, 12, 76-84. https://doi.org/10.1590/S1984-70332012000100010

Magalhães, A. C. N. (1986). Análise quantitativa de crescimento. In M. G. Ferri (Ed.), Fisiologia vegetal (Vol. 1, pp. 331-350). São Paulo: EDUSP.

Maguire, J. D. (1962). Speed of germination-aid in selection and evaluation for seedlings emergence and vigor. Crop Science, 2, 176-177. https://doi.org/10.2135/cropsci1962.0011183X000200020033x 
MAPA (Ministério da Agricultura, Pecuária e Abastecimento). (2009). Regras para análise de sementes (p. 399). Brasília: Secretaria de Defesa Agropecuária/MAPA/ACS. Retrieved from http://www.agricultura.gov.br/ assuntos/insumos-agropecuarios/arquivos-publicacoe-sinsmos/2946_regras_analise_sementes.pdf

Mariot, M. P., \& Barbieri, R. L. (2010). Divergência genética entre acessos de espinheira-santa (Maytenus ilicifolia Mart. Ex Reissek e M. aquifolium Mart.) com base em caracteres morfológicos e fisiológicos. Revista Brasileira de Plantas Medicinais, 12, 243-249. https://doi.org/10.1590/S1516-05722010000300001

Moura, N. F., Chaves, L. J., Naves, R. V., Aguiar, A. V., \& Sobierajski, G. R. (2013). Variability among provenances and progenies of Caryocar brasiliense Camb. Scientia Florestalis, 41, 103-112.

Nascimento, S. M., Cardoso, J. A., \& Cocozza, F. D. M. (2014). Physical and physicochemical characterization of 'mangabeira' fruits (Hancornia speciosa Gomes) in Western Bahia. Revista Brasileira Engenharia Agricola e Ambiental, 18, 856-860. https://doi.org/10.1590/1807-1929/agriambi.v18n08p856-860

Oliveira, S. A. G., Lopes, M. T. G., Chaves, F. C. M., Martins, C. C., \& Alves, E. U. (2013). Estimation of generic parameters of Plukenetia volubilis L. seed germination. Revista de Ciências Agrárias/Amazonian Journal of Agricultural and Environment Sciences, 56, 49-54.

Pereira, A. V., Pereira, E. B. C., Junqueira, N. T. V., \& Fialho, J. F. (2002). Enxertia de mudas de pequizeiro (p. 25). Planaltina, Embrapa Cerrados. Retrieved from https://ainfo.cnptia.embrapa.br/digital/bitstream/CPAC2009/24056/1/doc_66.pdf

Prete, C. E. C., \& Guerra, E. P. (1999). Qualidade fisiológica das sementes. In D. Destro, \& R. Montalván (Eds.), Melhoramento genético de plantas (Vol. 1, pp. 661-676). Londrina, UEL.

R Core Team. (2017). R: A Language and Environment for Statistical Computing. Vienna, Austria: R Foundation for Statistical Computing.

Rojas, W. (2003). Análisis multivariado em estudios de variabilidad genética, In T. Franco, \& R. Hidalgo (Eds.), Análisis estadístico del datos de caracterización morfológica de recursos fitogenéticos (Vol. 8, pp. 85-89). Roma, IPGRI.

SAS Institute. (2011). SAS/STAT User's guide (Version 9.1). Cary, USA, SAS Institute.

Silva, R. A. M., Mota, M. G. C., \& Farias Neto, J. T. (2009). Emergence and growth of seedling of bacabi (Oenocarpus mapora Karsten) and bacaba (Oenocarpus distichus Mart.) and estimates of genetics parameters. Acta Amazonica, 39, 601-608. https://doi.org/10.1590/S0044-59672009000300015

Vaughton, G., \& Ramsey, M. (1998). Sources and consequences of seed mass variation in Banksia marginata (Proteaceae). Journal of Ecology, 86, 563-573. https://doi.org/10.1046/j.1365-2745.1998.00279.x

Vechiato, M. H., \& Parisi, J. J. D. (2013). Importância da qualidade sanitária de sementes florestais na produção de mudas. Instituto Biológico, 75, 27-32.

Vieira Neto, R. D. (2002). Mangaba, In R. D. Vieira Neto (Ed.), Fruteiras potenciais para os tabuleiros costeiros e baixadas litorâneas (Vol. 1, pp. 115-140). Aracaju, Embrapa Tabuleiros Costeiros/Emdagro.

Vieira Neto, R. D., Silva Junior, J. F., \& Ledo, A. S. (2009). Mangaba. In J. A. Santos-Serejo, J. L. L. Dantas, C. V. S. Coelho, \& Y. S. Coelho (Eds.), Fruticultura tropical: espécies regionais e exóticas (Vol. 1, pp. 323-338). Brasília: Embrapa Informação Tecnológica.

Vieira, C. V., Souza, E. R. B., Belo, A. P. M., \& Camilo, Y. M. V. (2013). Development mangaba seedlings from fruits of different locations in the State of Goiás. Revista de Ciências Agrárias, 36, 363-371.

Vieira, M. C., Naves, R. V., Souza, E. R. B., Paula, M. S. P., Leandro, W. M., \& Moura, N. F. (2017). Biometria de frutos de Hancornia speciosa (Gomes) de ocorrência natural no Cerrado do Estado de Goiás. Scientific Electronic Archives, 10, 6-12.

Villachica, H. (1996). Frutales y hortalizas promisorios de la Amazonia. Lima, Tratado de Cooperación Amazonica.

Zuffo, A. M., Andrade, R. A., \& Zuffo Júnior, J. M. (2014). Biometric characterization of fruits and seeds baru (Dipteryx alata Vog.) in eastern Mato Grosso, Brazil. Revista de Ciências Agrárias, 37, 463-471.

Zuffo, A. M., Gesteira, G. S., Zuffo Júnior, J. M., Andrade, F. R., Soares, I. O., Zambiazzi, E. V., \& Santos, A. S. (2016). Biometric characterization of fruits and seeds mirindiba (Buchenavia tomentosa Eichler) and inajá (Attalea maripa [Aubl.] Mart.) in southern Piauí, Brazil. Revista de Ciências Agrárias, 39, 331-340. https://doi.org/10.19084/RCA15152 


\section{Copyrights}

Copyright for this article is retained by the author(s), with first publication rights granted to the journal.

This is an open-access article distributed under the terms and conditions of the Creative Commons Attribution license (http://creativecommons.org/licenses/by/4.0/). 